\title{
Analyzing U.S. nurse turnover: Are nurses leaving their jobs or the profession itself?
}

\author{
Olena Mazurenko ${ }^{* 1}$, Gouri Gupte ${ }^{2}$, Guogen Shan ${ }^{1}$ \\ ${ }^{1}$ Department of Health Care Administration and Policy, School of Community Health Sciences, University of Nevada, Las Vegas, \\ United States \\ ${ }^{2}$ Department of Health Policy and Management, School of Public Health, Boston University, United States
}

Received: March 3, 2015

DOI: $10.5430 /$ jha.v4n4p48
Accepted: May 3, 2015

URL: http://dx.doi.org/10.5430/jha.v4n4p48

\begin{abstract}
Objective: To examine and compare factors associated with making the decision to vacate a job (organizational turnover) versus leaving the profession (professional turnover) among registered nurses (RN) in the United States (U.S.).

Methods: Nationally representative data from the 2008 National Sample Survey of Registered Nurses was used. The sample consisted of 8,796 RNs who held an active RN license as of March 10, 2008, but changed a place of work or left the profession entirely. The analysis has been performed using SAS, version 9.3.

Results: The results of binary logistic regression revealed that RNs who reported work-related disability $(\mathrm{OR}=14.51 ; p$-value: $<$ $.001)$, illness $(\mathrm{OR}=3.32 ; p$-value: $<.001)$, experienced high physical demands $(\mathrm{OR}=1.57 ; p$-value: $<.001)$ or burnout $(\mathrm{OR}=$ $1.39 ; p$-value: <.001), were unsatisfied with their schedule $(\mathrm{OR}=2.16 ; p$-value: $<.001)$, or staffing arrangements $(\mathrm{OR}=1.41$; $p$-value: <.001) were more likely to leave the profession. Whereas RNs who reported high levels of stress $(\mathrm{OR}=0.59 ; p$-value: $<.001)$ were unsatisfied with the organization's leadership ( $\mathrm{OR}=0.22 ; p$-value: $<.001)$, unsatisfied with their opportunity to advance their career $(\mathrm{OR}=0.56$; $p$-value: $<.001)$, or were not adequately compensated $(\mathrm{OR}=0.63 ; p$-value: $<.001)$, were more likely to leave the organization.

Conclusions: Policy makers and health care managers should be aware of the different factors that are associated with RNs' decision to leave the profession or an organization. Health care managers involved in the development of nurse retention strategies should address organizational leadership and consider development of comprehensive career-development programs. Policy makers should consider allocating additional resources to ensure that RN workforce is of adequate size, is qualified, and is able to provide high quality care in the U.S..
\end{abstract}

Key Words: Registered nurse, Turnover, Retention, Recruitment

\section{INTRODUCTION}

The current United States (U.S.) nurse turnover rate is 16.5\% and is projected to increase over the next decade. ${ }^{[1]}$ Evidence suggests that increased nurse turnover results in decreased patient access, patient safety and quality of care leading to adverse patient outcomes. ${ }^{[2-5]}$ Simultaneously, nurse turnover also has a spillover effect on the remaining RNs by increasing their workload and job stress which leads to burnout and subsequently to further turnover. ${ }^{[2,6]}$ Nurse turnover can also adversely impact health care organizations' bottom line through higher recruitment and replacement costs. ${ }^{[7,8]}$

\footnotetext{
*Correspondence: Olena Mazurenko; Email: olena.mazurenko@unlv.edu; Address: Department of Health Care Administration and Policy, School of Community Health Sciences, University of Nevada, Las Vegas, United States.
} 
Despite ongoing research interest in nurse turnover, there is significant variation in how this is defined, ${ }^{[7]}$ ranging from the actual leaving the organization to the intent to leave in the near future. ${ }^{[9-11]}$ Furthermore, the direction of leaving, yet another dimension of job turnover, has received very little attention in the literature. ${ }^{[4]}$ The direction of leaving is the path that a registered nurse takes upon leaving an organization. An RN may change organization, but continue working in health care, referred to as organizational turnover, while another RN may leave the nursing field to work in a different industry, known as professional turnover. ${ }^{[12]}$ Finally, an $\mathrm{RN}$ may leave the job market altogether and either become permanently unemployed or retired, referred to as involuntary turnover. Evidence from the job satisfaction literature clearly indicates that an RN's satisfaction with the job of nursing and satisfaction with the occupation of nursing are two distinct concepts. ${ }^{[13,14]}$ The number of RNs dissatisfied with their job can have an impact on the nursing shortage in a given organization, but the number of nurses changing jobs does not reduce the total number of nurses in the labor force. However, when nurses become dissatisfied with nursing as a career choice, they may leave the profession altogether, depleting the nursing labor force. Previous research ${ }^{[13,14]}$ indicates that an RN's job satisfaction and satisfaction with occupation are influenced by different sets of factors. For example the work conditions at a given organization are more important for an RN's satisfaction with their current job, whereas the number of years until retirement is more important for an RN's satisfaction with their career and these concepts should be examined separately. Evidence suggests that similar situation is observed in the case of organizational and professional turnover. ${ }^{[15]}$ For instance, Simon et al. reported that the work/home interface and personal factors were associated with organizational turnover, whereas organizational leadership and local context had a greater impact on professional turnover among German nurses. ${ }^{[15]}$ To our knowledge, no research has been done to simultaneously examine and compare factors associated with organizational and professional turnover among RNs who left their organization or profession in the U.S..

The purpose of this study is to examine and compare factors associated with the decision by RNs to leave their profession or organization using nationally representative secondary data. The findings of this study will be of interest to health care managers involved in the design and implementation of nurse retention strategies as well as future recruitment initiatives. Additionally, our findings may be of interest to policy makers involved in the development of strategies aimed at ensuring that the nurse workforce is of adequate size, is qualified, and is able to provide high quality care in

Published by Sciedu Press the U.S..

\subsection{Conceptual framework}

Voluntary employee turnover has received considerable attention in management literature. ${ }^{[6,7,16]}$ Price's causal model of turnover has been widely applied to examine organizational turnover among RNs. ${ }^{[16]}$ This model suggests that a number of individual, organizational and environmental factors may be associated with an RN's decision to leave an organization. Given that this model has been widely applied and validated in the $\mathrm{RN}$ workforce this study adopted this model as a framework for examining factors associated with organizational turnover among RNs (see Figure 1). ${ }^{[16,17]}$ To our knowledge, there is no unified conceptual framework of professional turnover that could be easily adapted to the RN workforce. Therefore, we have relied on organizational behavior literature and scarce evidence from previous studies on RN professional turnover to identify potential factors for this study. Evidence suggests that job satisfaction is an important precursor of an employee's decision to leave the profession. ${ }^{[18,19]}$ Furthermore, it was shown that the social work environment, work organizational characteristics, workhome-interference and organizational commitment, which reflects employee's emotional attachment toward the occupation, were found to be associated with the decision by RNs to retire from the workforce, according to a large longitudinal European study. ${ }^{[20]}$ The detailed explanation of the main factors included in the models of organizational and professional turnover is discussed below.

\subsubsection{Individual factors}

Evidence relating individual factors to nurse turnover has been fairly consistent over time. Specifically, nurse age has been inversely related to organizational turnover, i.e. younger nurses are more likely to leave whereas older nurses are more committed to the organization. ${ }^{[9-11]}$ Other personal factors, such as having dependents in the household, were shown to be negatively associated with organizational and professional turnover. ${ }^{[4,21,22]}$

The relationship between nurses' level of education and organizational and professional turnover is less clear. Certain studies reported a positive relationship, with more educated nurses being more likely to leave an organization, whereas other studies suggested that nurses with higher educational levels (e.g. Master's degree) may have higher levels of professional commitment, and are therefore less likely to leave the profession. ${ }^{[22,23]}$

\subsubsection{Health-related factors}

Study findings uniformly agree that nurses who reported being stressed and burned out were more likely to leave their 
jobs, thus contributing to organizational turnover. ${ }^{[24]}$ For example, a sample of Canadian nurses reported that psychological exhaustion and unfairness influenced their decision to quit their jobs. ${ }^{[5]}$ Other physical demands and health related concerns such as disability have been positively associated with both professional and organizational turnover as well. ${ }^{[25]}$ Recent research also indicated that the absence of assistive technology or adequate workplace facilities may be the reason for low job satisfaction among individuals with disabilities. ${ }^{[25]}$

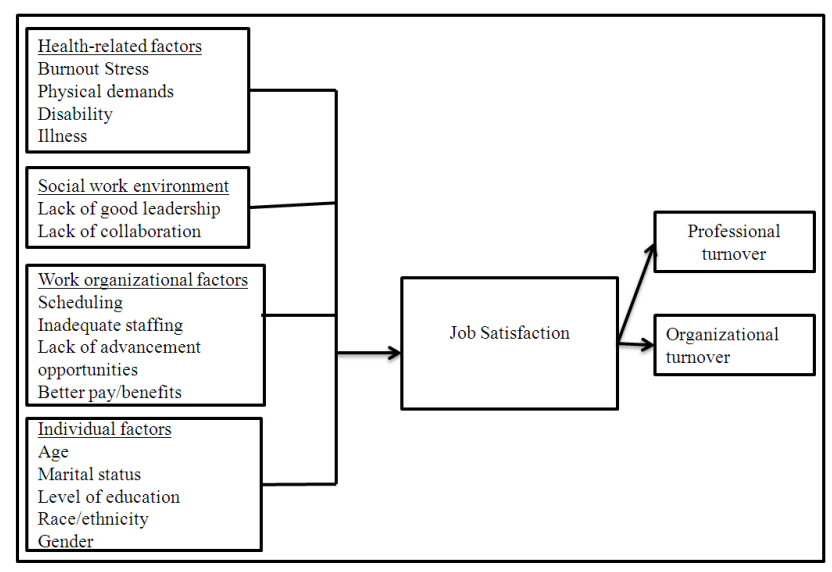

Figure 1. Model for studying nurse turnover based on the Price Model

\subsubsection{Social work environment}

The importance of leadership and effective management style on organizational and organizational turnover has been evident from previous empirical research. ${ }^{[26,27]}$ Raup I et al. showed that transformational leadership was associated with lower staff turnover trends in comparison with other leadership styles. ${ }^{[3,27]}$ More importantly, studies pointed out that the nurses' intent to leave their workplace and the subsequent organizational turnover are influenced more by supervisors than by co-workers, which can be due to the increased importance of mentoring in the nursing field. ${ }^{[10,28]}$ Studies have also specifically discussed the importance of teams and collaboration at the workplace to motivate employees to stay with an organization or within the nursing profession. ${ }^{[29,30]}$

\subsubsection{Work organizational factors}

Gardner et al. reported that nurses who disagreed with staffing and scheduling in their units were more likely to leave their jobs. ${ }^{[24]}$ Nurses' perceptions of advancement opportunities have been shown to influence turnover as well. A study of hospital-based nurses from ten European countries reported that nurses' perceptions about career development opportunities were associated with increased intent to leave both organization or profession. ${ }^{[21]}$ Pay and other benefits have been shown to influence nurses' intent to leave an organization and is more important for males than females. ${ }^{[23]}$ However, Frijters et al. reported that an increase in nurses' pay had a low impact on retention rates, which suggests that an increase in pay alone will not solve the organizational turnover issue. ${ }^{[31]}$

\subsubsection{Job satisfaction}

Job satisfaction can be defined as the extent to which an employee likes his or her job. ${ }^{[32]}$ It has been consistently associated with the intent to leave and actual organizational turnover. ${ }^{[33]}$ Nursing studies have generally estimated that a higher number of observed resignations are a result of job dissatisfaction rather than personal factors. ${ }^{[34,35]}$ Furthermore, Frijters and colleagues reported that job satisfaction was more important than the outside opportunities. ${ }^{[31]}$

\section{METHODS}

This study uses cross-sectional design to investigate whether similar predictors are associated with an RN's decision to leave the organization versus leaving the profession altogether. The data are derived from a publicly available secondary dataset, the National Sample Survey of Registered Nurses (NSSRN) 2008, which was collected by the Department of Health and Human Services. The NSSRN is based on a randomly selected sample of individual RNs from each state's register of licensed RNs. The data collection design was based on the stratified systematic sampling in each state with stratification by age level, dual license and employment commuting effects. Data were collected through postal surveys, internet-based surveys and direct interviews.

\subsection{Variables}

\subsubsection{Dependent variables}

A list of dependent variables and their explanation is presented in Table 1. The first dependent variable, i.e. organizational turnover, is derived by comparing respondents' current employment (2008) to employment one year prior (2007). Our second dependent variable, i.e. professional turnover, is derived by comparing the respondents' principal nursing position in 2008, at the time of the survey, to the principal nursing position in 2007 , a year before the survey.

\subsubsection{Independent variables}

Independent variables were derived from a single question that asked RNs to mark their primary reason(s) for employment change from a list of options. The question was: "Were any of the following the primary reason(s) for your employment change?" The following response options were provided: burnout, stress, physical demands, disability, illness, lack of good leadership, lack of collaboration, scheduling 
issues, inadequate staffing, lack of advancement opportuni- ing that this reason was relevant to the respondent's decision ties, better pay benefits, or other. Each response was entered to change employment. According to the NSSRN survey inas either "zero" indicating that this reason for employment strument, only respondents who derived their income solely change was not relevant to the respondent, or "one" indicat- from nursing filled this question.

Table 1. Dependent variables used in the study

\begin{tabular}{|c|c|c|c|}
\hline Construct & Measurement & Response categories & Transformations \\
\hline $\begin{array}{l}\text { Organizational } \\
\text { turnover }\end{array}$ & $\begin{array}{l}\text { Please indicate your employment } \\
\text { status in nursing in } 2008 \text { in } \\
\text { comparison to the employment } \\
\text { status in nursing in } 2007 .\end{array}$ & $\begin{array}{l}1 \text { = Same position/same employer as principal nursing } \\
\text { position on March 10, } 2008 \\
2 \text { = Different position/same employer as current one } \\
3 \text { = Different employer than current one } \\
4 \text { = Different position/employer or not working in } 2008\end{array}$ & $\begin{array}{l}1 \& 2=\text { zero (labeled as "stayers") } \\
3 \& 4=\text { one (labeled as "leavers") }\end{array}$ \\
\hline $\begin{array}{l}\text { Professional } \\
\text { turnover }\end{array}$ & $\begin{array}{l}\text { Please indicate your principal } \\
\text { nursing position in nursing in } \\
2008 \text {, in comparison to the } \\
\text { principal nursing position in } \\
\text { nursing in } 2007 \text {, a year before the } \\
\text { survey. }\end{array}$ & $\begin{array}{l}1 \text { = Full time RN in 2008/ full time RN in } 2007 \\
2 \text { = Full time RN in 2008/ part time RN in } 2007 \\
3 \text { = Full time RN in 2008/ Not employed } 2007 \\
4 \text { = Part time RN in 2008/ full time RN in } 2007 \\
5 \text { = Part time RN in 2008/part time in } 2007 \\
6 \text { = Part time RN in 2008/ Not Employed } 2007 \\
7 \text { = Not employed 2008/ full time RN in } 2007 \\
8=\text { Not employed 2008/ part time } 2007\end{array}$ & $\begin{array}{l}1-6=\text { zero (labeled as "stayers") } \\
7 \& 8=\text { one (labeled as "leavers") }\end{array}$ \\
\hline
\end{tabular}

Consistent with Price's turnover model and previous organizational behavior literature on occupational/professional turnover, ${ }^{[15,36]}$ we measured health-related factors using five variables: burnout, stress, physical demands, disability or illness. The social work environment was represented by two variables: leadership and collaboration. The work organizational factors were represented by four variables: scheduling, staffing, advancement opportunities and pay benefits. Job satisfaction was assessed using the question: "How satisfied are you with your principal job or with your most recent job, if you are not working now?", with six response options ranging from highly satisfied to highly dissatisfied.

Finally, the following individual variables were included in our model: age, marital status (categorized as married, widowed, and never married with children or not), level of education (categorized as diploma, associate, bachelor or master in nursing), race/ethnicity (categorized as white, nonHispanic and others), geographical location (rural or urban) and previous place of work (defined as hospital, outpatient setting, nursing home or other).

\subsection{Data analysis}

The unit of analysis for our study is the $\mathrm{RN}$ who either left the organization to work in a different health care setting or left the profession. As a first step, we examined the NSSRN database to identify "leavers" for our analysis and group them in one binary variable with value of "zero" assigned to organizational leavers and the value of "one" to professional leavers. Next, descriptive statistics, such as an examination of central tendencies and dispersion, were used to assess the data distribution and detect potential data anomalies. Then chi-square tests were employed to examine whether RNs who left the organization and RNs who left the profession differed with respect to demographics, education and place of work. Finally, binary logistic regression was employed to examine and compare factors associated with the RNs' decision to leave the profession or an organization. The following equation represents our model:

$\mathrm{RN}$ who left an organization or profession $=f$ (burnout, stress, physical demands, disability, illness, lack of good leadership, lack of collaboration, scheduling issues, inadequate staffing, lack of advancement opportunities, better pay benefits, age, marital status, level of education, race/ethnicity, geographical location, and previous place of work)

We have adopted a stepwise approach to our model, by entering only dependent variables, and health-related, social work environment, work organizational and individual factors in the first step. In the second step, we have added the variables that capture job satisfaction and occupational commitment. The statistical software used was SAS, version 9.3.

\section{Results}

The overall survey response rate was 62.4 percent. The descriptive characteristics of the study sample are presented in Table 2. Approximately 14 percent $(4,682)$ of RNs left the profession and 14 percent left their organization $(4,114)$ from a total sample size of 36,646 . Both groups were more likely to be White ( $88.7 \%$ and $82.9 \%$ respectively) and reside in urban areas (81.6\% and $83.7 \%)$. Nurses who left the profession were more likely to have bachelors in nursing 
$(34.7 \%)$, whereas the highest proportion of nurses who left the organization had an associate in nursing as their highest educational level (38.6\%). Furthermore, the largest group of RNs leaving the profession were working in a nursing home type setting (34.7\%) whereas the largest group of respondents leaving the organization were working in an outpatient setting $(38.6 \%)$. The majority of RNs who left the profes- sion were widowed/separated with children (54.2\%). On the other hand, the largest group of respondents who left their organization were married with no children $(46.7 \%)$. Finally, RNs below the age of 55 were more likely to leave the organization than the profession. However, after the age of 55, nurses were more likely to leave the profession, which could be associated with U.S. retirement policies.

Table 2. Descriptive characteristics of study sample $(\mathrm{N}=8,796)$

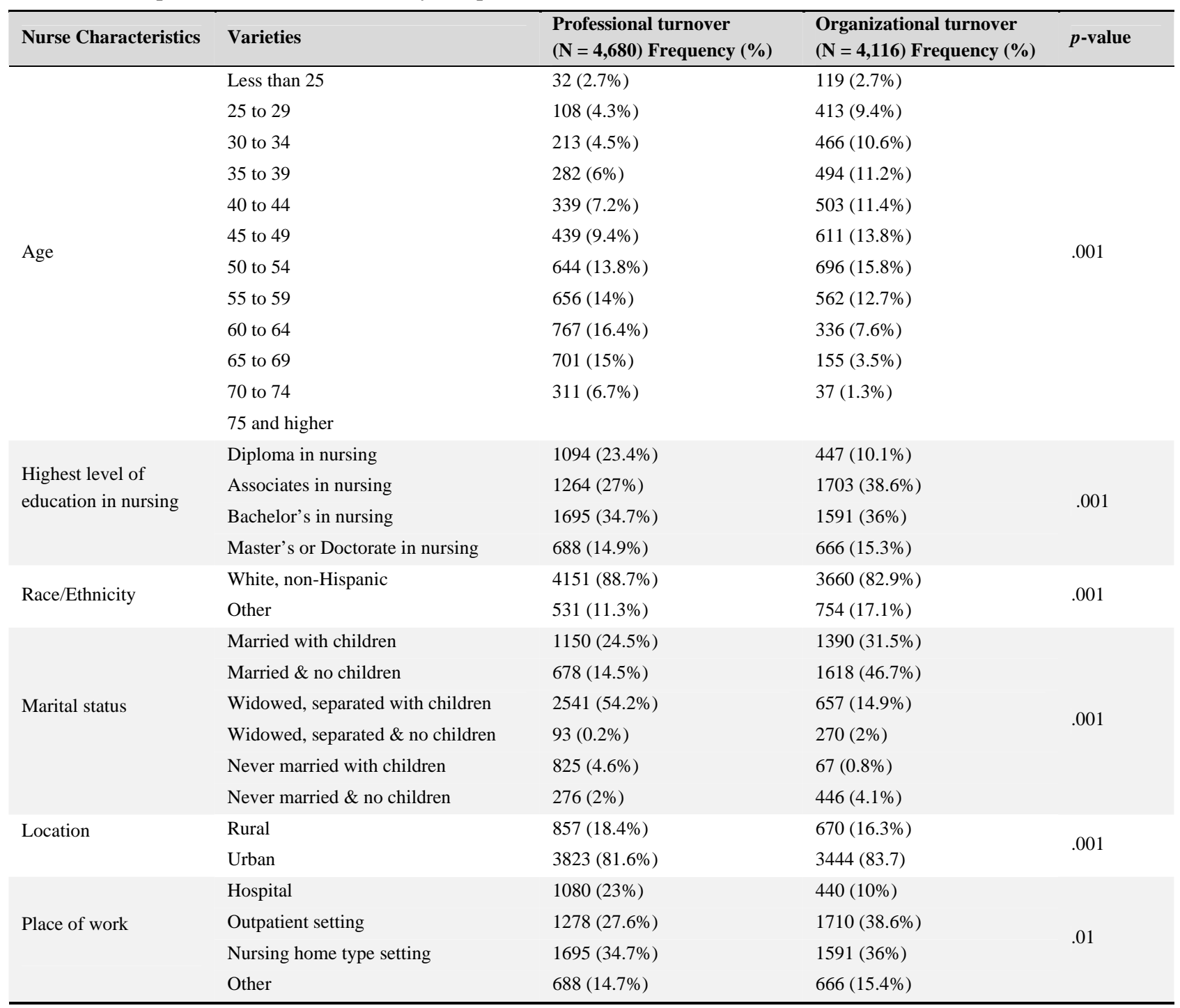

The results of the binary logistic regression are presented in Table 3. RNs who reported disability $(\mathrm{OR}=14.51$; $p$-value: $<.001)$ or illness $(\mathrm{OR}=3.32$; $p$-value: $<.001)$, or who experienced high physical demands $(\mathrm{OR}=1.57$; $p$-value: $<$ $.001)$ or burnout $(\mathrm{OR}=1.39$; $p$-value: $<.001)$, were more likely to leave the profession. RNs who were dissatisfied with their schedules $(\mathrm{OR}=2.16$; $p$-value: $<.001)$ and staffing $(\mathrm{OR}=1.41 ; p$-value: $<.001)$ were more likely to leave the profession; whereas RNs who reported high levels of stress $(\mathrm{OR}=0.59 ; p$-value: $<.001)$, were dissatisfied with the organization's leadership (OR $=0.22 ; p$-value: <.001) or advancement opportunity $(\mathrm{OR}=0.56$; $p$-value: $<.001)$ or compensation $(\mathrm{OR}=0.63$; $p$-value: $<.001)$ were more likely to leave the organization. Finally, nurses who were moderately satisfied with their most recent job $(\mathrm{OR}=0.79$; $p$-value: $<.01)$ were less likely to leave the profession than nurses 
who were extremely dissatisfied with their most recent job.

Table 3. Reasons for leaving the organization versus the profession: adjusted odds ratios $(\mathrm{N}=8,796)$

\begin{tabular}{|c|c|c|}
\hline Reasons for leaving & $\begin{array}{l}\text { Odds } \\
\text { Ratio }\end{array}$ & $\begin{array}{l}95 \% \\
\text { Confidence } \\
\text { Interval }\end{array}$ \\
\hline Burnout & $1.39^{* * *}$ & $1.12-1.72$ \\
\hline Stress & $.59^{* * *}$ & $0.49-0.72$ \\
\hline Disability & $14.51^{* * *}$ & $9.05-23.27$ \\
\hline Illness & $3.32^{* * *}$ & $2.16-5.10$ \\
\hline Physical & $1.57^{* * *}$ & $1.24-1.99$ \\
\hline Leadership & $.22^{* * *}$ & $0.17-0.27$ \\
\hline Collaboration & $1.12^{* * *}$ & $0.86-1.45$ \\
\hline Scheduling & $2.16^{* * *}$ & $1.80-2.60$ \\
\hline Staffing & $1.41^{* * *}$ & $1.13-1.75$ \\
\hline Opportunity & $.56^{* * *}$ & $0.43-0.73$ \\
\hline Salary & $.63^{* * *}$ & $0.53-0.75$ \\
\hline \multicolumn{3}{|l|}{ Job Satisfaction } \\
\hline Extremely satisfied & .94 & $0.67-1.32$ \\
\hline Moderately satisfied & $.79^{*}$ & $0.56-1.00$ \\
\hline Neither satisfied nor dissatisfied & .90 & $0.61-1.32$ \\
\hline Moderately dissatisfied & .91 & $0.62-1.33$ \\
\hline Extremely dissatisfied & Reference & \\
\hline Age & $1.68^{* * *}$ & $1.62-1.74$ \\
\hline \multicolumn{3}{|l|}{ Kinship responsibility } \\
\hline Married with children & $2.85^{* * *}$ & $2.15-3.77$ \\
\hline Married \& no children & 1.28 & $0.97-1.69$ \\
\hline Widowed, separated with children & .88 & $0.58-1.34$ \\
\hline Widowed, separated \& no children & $.62^{* * *}$ & $0.45-0.85$ \\
\hline Never married with children & .98 & $0.41-2.33$ \\
\hline Never married \& no children & Reference & Reference \\
\hline \multicolumn{3}{|l|}{ Highest level of education } \\
\hline Diploma in vs. Master's or Doctorate & $1.60^{* * *}$ & $1.28-2.01$ \\
\hline Associates in vs. Master's or Doctorate & $.68^{* * *}$ & $0.57-0.82$ \\
\hline Bachelor's vs. Master’s or Doctorate & $1.37^{* * *}$ & $1.13-1.63$ \\
\hline Race (non-White-reference category) & $1.19^{* * *}$ & $1.14-1.64$ \\
\hline Location (rural-reference category) & $2.56^{* *}$ & $1.34-3.45$ \\
\hline \multicolumn{3}{|l|}{ Place of work } \\
\hline Hospital & $1.45^{* * *}$ & $0.98-4.56$ \\
\hline Outpatient setting & .88 & $0.67-1.34$ \\
\hline Nursing home type setting & .65 & $0.34-1.45$ \\
\hline Other & Reference & Reference \\
\hline
\end{tabular}

Several individual characteristics were associated with RNs' organizational or professional turnover. Specifically, older nurses $(\mathrm{OR}=1.68 ; p$-value: $<.001)$ and nurses who were married with children $(\mathrm{OR}=2.85 ; p$-value: $<.001)$ were more likely to leave the profession than nurses who never married and had no children. Conversely, nurses who were widowed with children $(\mathrm{OR}=0.62 ; p$-value: $<.001)$ were more likely to leave the organization than nurses who never married and had no children. Nurses with a diploma (OR $=1.60 ; p$-value: <.001) or a bachelor's degree in nursing $(\mathrm{OR}=1.37 ; p$-value: $<.001)$ were more likely to leave the profession than nurses with a master's or doctorate degree in nursing. RNs located in urban areas $(\mathrm{OR}=2.56 ; p$-value: $<$ $.05)$ and previously employed in the hospitals $(\mathrm{OR}=1.45$; $p$-value: <.001) were more likely to leave the profession.

\section{DiscuSSION}

Given the increasing nurse turnover rates, ${ }^{[1,37]}$ it is important to understand why RNs are leaving health care organizations or the profession altogether. This study's analysis indicates that health-related factors such as reported disability or illness due to the work-related injuries, and high physical demands were associated with RNs' decision to leave the profession. The rates of work-related illnesses, such as musculoskeletal injury, increased by $52 \%$ and $62 \%$ respectively between 1980 and 1993 and this is still one of the leading causes of work-related disabilities. ${ }^{[38]}$ Research has shown that work-related injuries are predominantly caused by situational factors, such as staffing levels, availability of lifting devices, consistently heavy workload (e.g. 12 hour shifts) and high levels of stress. ${ }^{[38,39]}$ The findings in this study highlight the need for customized organizational approach that could address potentially unsafe staffing levels, reduce the workload for individual nurses, and streamline scheduling requirements in each facility.

Corroborating previous research, our study revealed that nurses were more likely to leave an organization if they reported high levels of stress or were dissatisfied with the organization's leadership, their advancement opportunity, and/or their compensation. ${ }^{[11]}$ Therefore, health care managers should develop and implement setting-specific career enhancement programs for RNs that would adequately reflect their needs. Some of the suggested areas for increasing the engagement of nurses are quality improvement methodology and leadership training, as identified by previous research. ${ }^{[40]}$ Additionally, health care managers should consider adopting a supportive leadership style that will increase the retention of nurses. Currently this is used in less than $10 \%$ of nurse workplaces. ${ }^{[29]}$

Several personal characteristics were shown to be associated with organizational and professional turnover. Contrary to the previous research, this study shows that older nurses are more likely to leave the profession. ${ }^{[9,41]}$ The results pointed out that despite an organizational commitment, older nurses can be considered a "high risk" group with respect to the likelihood of leaving the nursing field altogether. Older nurses have extensive experience in care delivery process; thus, cohort-specific initiatives that would increase the re- 
tention of this group should be developed. These initiatives include an assessment of the needs and satisfaction levels of mid-career nurses, an improvement to ergonomic equipment and design in the workplace, education to facilitate transition into new roles, expanding or carving out new roles for older nurses, phased retirement options, and injury-prevention programs. These initiatives may also motivate younger nurses and help organizations to meet their occupational safety requirements. ${ }^{[42-44]}$

Kinship responsibilities (e.g. being married with children) were associated with organizational and professional turnover in different ways. RNs who are married with children or widowed with children are more likely to leave the profession than never-married nurses without children. This difference could be explained by a higher need for workhome balance among married $\mathrm{RNs},{ }^{[15]}$ or conversely, as explained in other industry turnover literature, it may be true that married people are more likely to be able to leave the profession and stay at home due to spousal income support. ${ }^{[45]}$ There are several existing programs within the industry which have already successfully improved family-work balance, such as offering flexible schedule, career breaks or the provision of special leave for employees with elder care responsibilities. ${ }^{[45]}$

Finally, this study found that RNs who worked in urban areas or in hospitals were more likely to leave the profession rather than organization. This may be explained by the fact that RNs located in urban areas have more job opportunities and may be more likely to choose different occupations if they are dissatisfied. ${ }^{[15]}$ Therefore, management in urban settings needs to pay additional attention to the development of strategies that include training, better schedules, more organizational engagement activities, incentives and award structures.

\section{Limitations}

This study has both strengths and limitations worth noting. It is the first study to analyze the differences between organizational and professional turnover using a nationally representative sample of RNs practicing in the U.S.. Unlike the majority of nurse turnover research, this study was able to examine predictors of turnover among RNs who already left an organization or profession rather than simply stating their intention to leave. Thus, the analysis reflects the actual "turnover process" better than previous research. Despite these strengths, this study is limited in several ways. Although this study is based on a representative dataset, the information about reasons for turnover was obtained from subjective self-reported data by RNs who had left the orga- nization or the profession. Therefore, our results may suffer from "memorability" bias, ${ }^{[46]}$ for example nurses may report different reasons for leaving an organization than they actually had at the time of departure. Although the vast majority of research in this field has relied on self-reported data obtained from individual nurses, future research should consider collecting this type of information directly at the time of the nurse's departure in order to obtain more accurate information. Given the analytical approach of this study, e.g. focusing only on "leavers", it is not possible to directly compare our findings with previous research that is based on data from nurses still working in the profession and those who left it. Furthermore, the dataset limits our ability to consider other factors that may influence RN's decision to leave the profession including unemployment rate, recession, availability of other jobs in the market, and government policies, e.g. Affordable Care Act, ${ }^{[47]}$ that may affect the job market. Finally, due to the cross-sectional nature of the data, the identified relationships can be interpreted as associations only. Thus, subsequent studies should consider adopting longitudinal designs to shed a light on "causal" relationships between predictors of organizational and professional turnover and actual turnover among RNs.

\section{Conclusions}

Our study revealed that different sets of factors are associated with organizational and professional turnover among RNs who practice in the U.S.. This knowledge is important for health care managers due to the fact that higher RN turnover is known to be associated with organizational shortages, absenteeism and lower morale of remaining staff. Thus, health care organizations that are interested in attracting and retaining RNs in their institution should consider introducing participative leadership and comprehensive career development programs. Health care administrators should also consider designing and implementing customized nurse staffing requirements to address occupational safety in a given facility. Furthermore, health care managers should be concerned about the factors that are associated with RNs' decision to leave the profession due to the shrinking size of the active RN workforce and looming nursing shortages. Finally, policy makers should consider allocating additional resources to ensure that RN workforce is of adequate size, is qualified, and is able to provide high quality care by addressing factors that were shown to be associated with RN's decision to leave the workforce. By carefully understanding predictors of organizational and professional turnover among RNs, health care managers and policy makers can better tailor strategic initiatives to maximize RNs retention in the workforce. 


\section{REFERENCES}

[1] Nursing Solutions. National healthcare and RN retention report. 2014. [cited 2014 April 22]. Available from: http://www.nsinursing solutions.com/

[2] Aiken LH, Clarke SP, Sloane DM, et al. Hospital nurse staffing and patient mortality, nurse burnout, and job dissatisfaction. JAMA: The Journal of the American Medical Association. 2002; 288(16): 198793. PMid: 12387650. http://dx.doi.org/10.1001/jama. 288. 16.1987

[3] Duffield CM, Roche MA, Homer C, et al. A comparative review of nurse turnover rates and costs across countries. Journal of Advanced Nursing. 2014; 70(12): 2703-12. PMid: 25052582. http: //dx.doi.org/10.1111/jan.12483

[4] McCarthy G, Tyrrell MP, Lehane E. Intention to'leave'or'stay'in nursing. Journal of Nursing Management. 2007; 15(3): 248-55. PMid: 17359424. http://dx.doi.org/10.1111/j.1365-2834. 2007.00648.x

[5] O'Brien-Pallas L, Griffin P, Shamian J, et al. The impact of nurse turnover on patient, nurse, and system outcomes: a pilot study and focus for a multicenter international study. Policy, Politics, \& Nursing Practice. 2006; 7(3): 169-79. PMid: 17071704. http: //dx.doi.org/10.1177/1527154406291936

[6] Van Breukelen W, Van der Vlist R, Steensma H. Voluntary employee turnover: Combining variables from the 'traditional'turnover literature with the theory of planned behavior. Journal of Organizational Behavior. 2004; 25(7): 893-914. http://dx.doi.org/10.1002 /job. 281

[7] Hayes LJ, O'Brien-Pallas L, Duffield C, et al. Nurse turnover: a literature review-an update. International Journal of Nursing Studies. 2012; 49(7): 887-905. PMid: 22019402. http://dx.doi.org/10. 1016/j.ijnurstu.2011.10.001

[8] Li Y, Jones CB. A literature review of nursing turnover costs. Journal of Nursing Management. 2013; 21(3): 405-18. PMid: 23406301. http://dx.doi.org/10.1111/j.1365-2834.2012.01411.x

[9] Chan MF, Luk AL, Leong SM, et al. Factors influencing Macao nurses' intention to leave current employment. Journal of Clinical Nursing. 2009; 18(6): 893-901. PMid: 19239668.

[10] Delobelle P, Rawlinson JL, Ntuli S, et al. Job satisfaction and turnover intent of primary healthcare nurses in rural South Africa: a questionnaire survey. Journal of Advanced Nursing. 2011; 67(2): 371-83. PMid: 21044134. http://dx.doi.org/10.1111/j.1365-2648. 2010.05496.x

[11] LeVasseur SA, Wang CY, Mathews B, et al. Generational differences in registered nurse turnover. Policy, Politics, \& Nursing Practice. 2009; 10(3): 212-23. PMid: 20026454. http://dx.doi.org/10. $1177 / 1527154409356477$

[12] Kirschenbaum A, Weisberg J. Employee's turnover intentions and job destination choices. Journal of Organizational Behavior. 2001; 23(1): 109-25. http://dx.doi.org/10.1002/job.124

[13] Ingersoll GL, Olsan T, Drew-Cates J, et al. Nurses' job satisfaction, organizational commitment, and career intent. Journal of Nursing Administration. 2002; 32(5): 250-63. PMid: 12021566. http://dx.doi.org/10.1097/00005110-200205000-00005

[14] Shaver KH, Lacey LM. Job and career satisfaction among staff nurses: effects of job setting and environment. Journal of Nursing Administration. 2003; 33(3): 166-72. PMid: 12629304. http: //dx.doi.org/10.1097/00005110-200303000-00008

[15] Simon M, Müller BH, Hasselhorn HM. Leaving the organization or the profession-a multilevel analysis of nurses' intentions. Journal of Advanced Nursing. 2010; 66(3): 616-26. PMid: 20423396. http://dx.doi.org/10.1111/j.1365-2648.2009.05204.x

Published by Sciedu Press
[16] Price JL, Mueller CW. A causal model of turnover for nurses. Academy of Management Journal. 1981; 24: 543-65. PMid: 10252608. http://dx.doi.org/10.2307/255574

[17] Price JL. Reflections on the determinants of voluntary turnover International Journal of Manpower. 2001; 22(7): 600-24. http: //dx.doi.org/10.1108/EUM0000000006233

[18] Griffeth RW, Hom PW, Gaertner S. A meta-analysis of antecedents and correlates of employee turnover: Update, moderator tests, and research implications for the next millennium. Journal of Management. 2000; 26(3): 463-88. http://dx.doi .org/10.1177/014920630 002600305

[19] Maertz CP, Campion MA. 25 years of voluntary turnover research: a review and critique. 1998; 49-81.

[20] Lee K, Carswell JJ, Allen NJ. A meta-analytic review of occupational commitment: relations with person-and work-related variables. Journal of Applied Psychology. 2000; 85(5): 799. PMid: 11055151 http://dx.doi.org/10.1037/0021-9010.85.5.799

[21] Estryn-Béhar M, Heijden V, Oginska H, et al. The impact of social work environment, teamwork characteristics, burnout, and personal factors upon intent to leave among European nurses. Medical Care. 2007; 45(10): 939-50. PMid: 17890991. http://dx.doi .org/10. 1097/MLR . 0b013e31806728d8

[22] Stewart NJ, D'Arcy C, Kosteniuk J, et al. Moving on? Predictors of intent to leave among rural and remote RNs in Canada. The Journal of Rural Health. 2011; 27(1): 103-13. PMid: 21204977. http://dx.doi.org/10.1111/j.1748-0361.2010.00308.x

[23] Borkowski N, Amann R, Song SH, et al. Nurses' intent to leave the profession: Issues related to gender, ethnicity, and educational level. Health Care Management Review. 2007; 32(2): 160-7. PMid: 17438399. http://dx.doi.org/10.1097/01. HMR.0000 267793.47803.41

[24] Gardner JK, Thomas-Hawkins C, Fogg L, et al. The relationship between nurses' perceptions of the hemodialysis unit work environment and nurse turnover, patient satisfaction, and hospitalizations. Nephrology Nursing Journal. 2007; 34(3): 271. PMid: 17644871.

[25] Uppal S. Disability, workplace characteristics and job satisfaction. International Journal of Manpower. 2005; 26(4): 336-49. http: //dx.doi.org/10.1108/01437720510609537

[26] Gormely DK. Are we on the same page? Staff nurse and manager perceptions of work environment, quality of care and anticipated nurse turnover. Journal of Nursing Management. 2011; 19(1): 33-40. PMid: 21223403. http://dx.doi.org/10.1111/j.1365-2834. 2010.01163.x

[27] Raup GH. The impact of ED nurse manager leadership style on staff nurse turnover and patient satisfaction in academic health center hospitals. Journal of emergency nursing: JEN: official publication of the Emergency Department Nurses Association. 2008; 34(5): 403. PMid: 18804712. http://dx.doi.org/10.1016/j.jen. 2007. 08.020

[28] Leiter MP, Price SL, Spence Laschinger HK. Generational differences in distress, attitudes and incivility among nurses. Journal of Nursing Management. 2010; 18(8): 970-80. PMid: 21073569. http://dx.doi.org/10.1111/j.1365-2834.2010.01168.x

[29] Apker J, Ford W, Fox DH. Predicting nurses' organizational and professional identification: the effect of nursing roles, professional autonomy, and supportive communication. Nursing Economics. 2003; 21(5): 226. PMid: 14618972.

[30] Duffield CM, Roche MA, Blay N, et al. Nursing unit managers, staff retention and the work environment. Journal of Clinical Nursing. 2011; 20(1-2): 23-33. PMid: 21158986. http://dx.doi .org/10. $1111 / j .1365-2702.2010 .03478 . x$ 
[31] Frijters P, Shields MA, Price SW. Investigating the quitting decision of nurses: panel data evidence from the British National Health Service. Health Economics. 2006; 16(1): 57-73. PMid: 16929471. http://dx.doi.org/10.1002/hec.1144

[32] Oldham GR, Hackman JR. Not what it was and not what it will be: The future of job design research. Journal of Organizational Behavior. 2010; 31(2-3): 463-79. http://dx.doi.org/10.1002/job.678

[33] Coomber B, Louise Barriball K. Impact of job satisfaction components on intent to leave and turnover for hospital-based nurses: a review of the research literature. International Journal of Nursing Studies. 2007; 44(2): 297-314. PMid: 16631760. http://dx.doi .org/10.1016/j.ijnurstu.2006.02.004

[34] Nagy MS. Using a single-item approach to measure facet job satisfaction. Journal of Occupational and Organizational Psychology. 2002; 75(1): 77-86. http://dx.doi.org/10.1348/096317902 167658

[35] Weisman CS, Alexander CS, Chase GA. Determinants of hospital staff nurse turnover. Medical Care. 1981; 19(4): 431-443. PMid: 7230936. http://dx.doi.org/10.1097/00005650-198 104000-00005

[36] Hasselhorn HM, Tackenberg P, Müller B, et al. Working conditions and intent to leave the profession among nursing staff in Europe. Arbetslivsinstitutet: Förlagstjänst; 2003.

[37] Littlejohn L, Campbell J, Collins-McNeil J, et al. Nursing shortage: A comparative analysis. International Journal of Nursing. 2012; 1(1): 22-7.

[38] Institute of Medicine. Staffing and work-related injuries and stress. Washington: DC; 1996.
[39] Strachota E, Normandin P, O'Brien N, et al. Reasons registered nurses leave or change employment status. Journal of Nursing Administration. 2003; 33(2): 111-7. PMid: 12584464. http://dx.d oi.org/10.1097/00005110-200302000-00008

[40] Buerhaus PI, Staiger D, Auerbach DI. The future of the nursing workforce in the United States: Data, trends, and implications: Jones and Bartlett Sudbury, MA; 2009.

[41] Camerino D, Conway PM, Van der Heijden BIJ, et al. Low-perceived work ability, ageing and intention to leave nursing: a comparison among 10 European countries. Journal of Advanced Nursing. 2006; 56(5): 542-52. PMid: 17078829. http://dx.doi.org/10.1111 /j.1365-2648.2006.04046.x

[42] Blay N, Duffield CM, Gallagher R, et al. A systematic review of time studies to assess the impact of patient transfers on nurse workload. International Journal of Nursing Practice. 2014; 20(6): 662-73. PMid: 24689656. http://dx.doi.org/10.1111/ijn.12290

[43] Coshow SM, Davis P, Wolosin RJ. The 'Big Dip': decrements in RN satisfaction at mid-career. Nursing Economics. 2009; 27(1): 15 PMid: 19331308.

[44] Hatcher BJ, Bleich MR. Wisdom at work: The importance of the older and experienced nurse in the workplace. Robert Wood Johnson Foundation; 2006.

[45] Scheibl F, Dex S. Should we have more family-friendly policies? European Management Journal. 1998: 16(5): 586-99. http://dx.d oi .org/10.1016/S0263-2373(98)00035-8

[46] Choi B, Pak A. A catalog of biases in questionnaires. Preventing Chronic Disease. 2005; 2(1): A13. PMid: 15670466.

[47] Patient Protection and Affordable Care Act, 42 U.S.C. § 18001 et seq. 2010 . 